\title{
The Research for Exploring Product Design Characteristics by SEM via Correlated Innovation and Design Strategy
}

\section{Yen Hsu}

Department of Industrial Design, Ming Chi University of Technology, Taipei, Taiwan.

Email: erickshi@ms1.hinet.net

Received September $4^{\text {th }}, 2012$; revised October $7^{\text {th }}, 2012$; accepted November $8^{\text {th }}, 2012$

\begin{abstract}
Managers at NPD departments of Taiwan consumer electronic industry were interviewed to explore the effects innovation strategy (IS) has on design strategy (DS) and finally on product design characteristics (DC). The fitness of theoretical models and the observed data was examined. A questionnaire survey was conducted. 1300 enterprises in Taiwan consumer electronic industry were randomly selected as the survey pool. At last, 370 effective questionnaires were collected. Their responses on the questionnaires were analyzed to test the fitness of the model with structural equation modeling analysis (SEM). A proper fitness was found for the correlation theoretical model of IS, DS, DC, and the observed data. In enterprises, IS will influence product DC, and at the same time, IS will influence product DC through DS. Among these three variables, DS serves as an independent variable and intervene variable to DC.
\end{abstract}

Keywords: Design Characteristics; Innovation Strategy; Design Strategy; SEM

\section{Introduction}

Innovation is the only one and most effective survival ability for enterprises to face the future [1]. And constant innovation will help trigger the business growth and keep the leading priority in enterprises [2,3]. More importantly, rapid launch new products into the market place will help enterprises to break bottlenecks, even to turn the defeat into victory, particularly in a time of business recession [4-7].

Thanks to the modern appearance of diversity in function, Taiwan electronics products have created many famous global brands, including Acer, Asus, Benq, HTC, and so on (Figure 1).

However, the global financial tsunami in 2008 had cast widespread impacts on enterprises in Taiwan and all over the world. For R\&D personnel and product designers in these enterprises, not only do they have to pay close attention to the challenges from the change in the market place and take immediate responses to the actions from competitors, but they also need to complete the new product development by subtle product design according to the innovation strategy (IS) in the enterprises [8-12].

In April 24, 2006, Business Week announced the most innovative 100 enterprises in the world. These enterprises are highly creative and innovative in the products, user interface, and total service they offer [13]. A trend can be found from these innovative enterprises: an efficient product innovation or development of service is not only the lifeblood for survival but also the motive power for enterprises to keep the priority in competition [14-19]. Therefore, studies regarding how to efficiently integrate the innovation procedure in enterprises to uplift the performance of new product development are still growing [20-31].

In much related literature, design is considered as an integral resource in enterprises, a mechanism for the integration of product development, and a serial loop in the total value chain of enterprises [32-38]. However, in the practical execution of product development, it is a challenge for designers to manipulate product design so as to reach the innovation goal in an enterprise. In studies of [31,39], it has been found that enterprises have certain practical ways in product design. However, rare literature can be found in the relation model between enterprise's innovation strategy and design strategy (DS).

In this study, managers in innovation and R\&D divi-

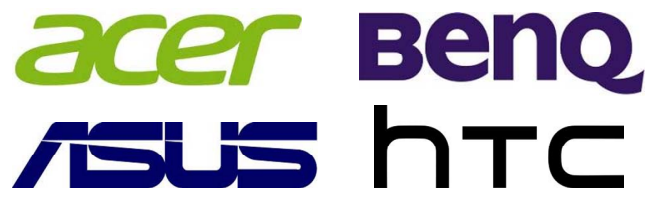

Figure 1. Famous global brands of Taiwan. 
sions in Taiwanese consumer electronic industry were interviewed to explore the adaptive situation of the survey data in terms of the theoretical models. The effects innovation strategy has on design characteristics (DC) were then investigated. At last, whether innovation strategy would influence design strategy and the final design characteristics of products was examined.

\section{Literature Review and Framework Development}

\subsection{Effects of IS on DS}

Innovation strategy refers to the idea that an enterprise is able to provide an environment for creativity and innovation condition in which it can offer unique products or services different from other competitors [40]. With their resources and techniques, enterprises can process various combinations to generate different innovation strategies from which they can execute their enterprise policy and promote their performance [41-43].

Literature related to innovation strategy can be roughly divided into three categories: 1) Technical innovation strategy including a higher ratio of $R \& D$ expense in the revenue [44], being aggressive in the application of logo, royalty, and patents [43], frequent introduction of new techniques to improve production or manufacturing procedure $[14,45]$, constant improvement of the production procedure [46], and the like to achieve enterprises' goal; 2) Commercial innovation strategy including to bring up innovative products or services $[47,48]$, to improve, renew, or extend current products or add new product lines $[4,48]$, to change or relocate the target customer group [49], and so on; 3) Management innovation strategy includes the timely adoption of proper response strategy, build up and control the distribution channel so as to cope with the change in outer environment [47,50], to solve the customer's complaints in time [47], to adopt new management methods to promote the performance in the organization and to encourage customers to innovate by raising wage or welfare system [51,52], to stimulate R\&D personnel to innovate by a proper performance measurement system [42], etc.

In processing product innovation, each strategic hierarchy in the enterprise should operate in coordination to implement the total policy of the company [18,53-55]. According to the goal set in innovation strategy, in addition, an enterprise needs to collocate the practical product design task and integrate the innovation resource in the enterprise so as to work out new products through crossorganization communication and coordination [56-59]. Based upon the above concepts of innovation strategy, a hypothesis is offered for the relationship between innovation strategy and design strategy. It is listed below:

H1. Innovation strategy has a positive effect on design strategy.

\subsection{Effects of IS on DC}

To reach the goal of product-variety marketing and provide varying products for customers, enterprises will emphasize the design characteristics of their products for market segmentation in their product innovation. According to Baxter, product design characteristics contain styling context, product symbolism, product function, and the like points of view [32]. From the viewpoint of product design specification (PDS), Pugh looks into the perspectives of product performance, product life in service, maintenance, product size, product weight, aesthetics, appearance and finish, materials, product life span, standards and specifications, ergonomics, quality and reliability, product shelf life, testing, safety, product legal liability, installation and operation, and product disposal [6].

Moreover, Chang categorized the key points of product design into the following five facets: 1) change in product function, for example, change of product capability, function, and structure; 2) change in product use such as change in operation, carry along, maintenance, and storage; 3) change in product style including the change in product form, color, and graphics; 4) change in product cost including change of the manufacturing cost and marketing cost; and 5) change in product package such as change of product packaging design as a part of the product design strategy [60]. Hsu claim that product design characteristics can make possible the marketization of innovation strategy and can serve as the concrete criteria for the innovation analysis [31,39]. Another hypothesis, therefore, is offered in this study:

H2. Innovation strategy has a positive effect on design characteristics.

\subsection{Effects of DS on DC}

The design strategy is referred to as the way how an enterprise processes new product design under the guideline of total enterprise strategy [61]. In the similar viewpoint, Olson et al. consider design strategy an effective way of allocation and coordination of the design resource in order to fulfill the company goal [62]. Consequently, Oakley pinpoints that design strategy and enterprise strategy are mutually dependent [63]. Mozota quoted three basic strategies from the competition strategies of Porter to describe the purposes of design strategy, including design for cost, design for image, and design for focus [16, 64].

In addition, Kelley analyzed successful product design cases and proposed a strategic color palette in which the design strategy is composed of 12 strategic factors [65]. Moreover, Sung and You considers that design strategy 
belongs to the tangible response to the design innovation activity in an organization [66].

Furthermore, Sung and You integrated Kelley's design strategic factors [65] and specified ten product design innovation factors. According to Sung and You, design strategy is composed of a series of strategically related design property and can be used to achieve the goal of product design innovation, making it possible for an enterprise to possess the unique advantageous edge in design competition [66].

Therefore, design strategy refers to the way for the execution of product innovation, analysis of the customer demand and the influences from competitors, and the approach to fulfilling the enterprise's performance goal by the design team through the coordination of the core R\&D ability in the company [31]. Studies from Hsu attempted to analyze the product design in enterprises from the aspects of innovation type, design feature, target market, and design appeal and he considers design characteristics the concrete practice of design strategy $[39,67]$. As a result, a third hypothesis is offered in the study:

H3. Design strategy has a positive effect on design characteristics.

According to the above literature review, a conceptual research framework covering $\mathrm{H} 1 \sim \mathrm{H} 3$ is illustrated in Figure 2.

\section{Method}

\subsection{Variable Definition and Measurement}

The variables for innovation strategy, design strategy, and design characteristics are listed in Table 1. Variables related to innovation strategy cover three major strategic dimensions. The variables regarding technical innovation strategy are primarily selected from [4,43,45-46]. The variables about commercial innovation strategy are principally from $[4,45,47-49]$. The variables about management innovation strategy are mainly chosen from $[42,47$, 50-52]. As far as design strategy is concerned, variables include four major strategic dimensions: reinforcing R\&D ability, reinforcing R\&D ability, reducing production cost, ensuring product quality, and uplifting enterprise image, which are majorly selected from $[31,66]$. At last, variables regarding design characteristics contain product function, operation, appearance, and cost dimensions, which are chosen from $[31,39]$.

\subsection{Research Setting, Sample and Data Collection}

In this study, the members in Taiwan Electrical and Electronic Manufacturers' Association (TEEMA) were used as the survey pool. The survey is divided into the pilot test and the formal questionnaire survey.

At the pilot test stage, focus group interview (FGI) was used to specify the target user group, the research limit, and the relations among variable dimensions. Seven experts (four experienced managers and three expert scholars) were invited to verify whether the variables extracted from literature were suitable. In the pilot test, the experts were asked to respond their degrees of agreement in each question on a 5-point Likert scale. On the scale, 1 means "never or do not agree at all" and 5 means "always or totally agree." (The definitions of variables are listed in Appendix).

In this stage, 30 enterprises were obtained. From factor analysis and reliability analysis, the construct validity and reliability were examined. The result demonstrated that the extracted factor could fully explain the variance, indicating a high construct validity. Moreover, the Cronbach's $\alpha$ for each variable was higher than 0.8 , meaning that the survey questions had proper reliability.

In the formal questionnaire survey, 1300 enterprises were randomly selected from TEEMA, from which managers at the NPD divisions were interviewed. After repeated contacts, 370 enterprises were obtained, reaching $28.46 \%$ of effective survey samples.

\section{Data Analysis and Results}

\subsection{Data Accuracy Analysis}

Table 2 lists the mean, standard deviation, and correlation matrix of each variable dimension. Table 3 lists the composite reliability (CR) for each dimension: $0.89,0.87$ and 0.91 , respectively and the total CR of 0.89 , above the standard 0.70 [68], indicating a good consistency in the model. In addition, the average variance extracted (AVE) for each dimension was $0.73,0.75$ and 0.79 , respectively.

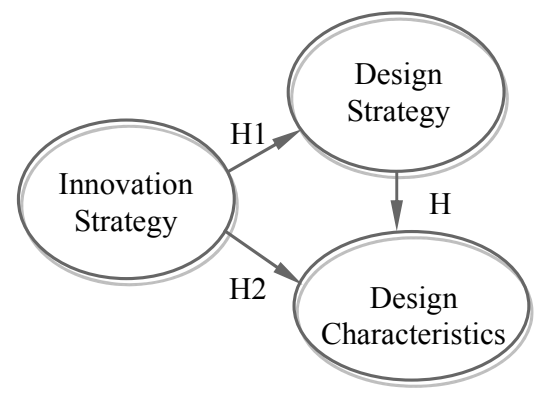

Figure 2. The conceptual model of innovation strategy, design strategy, and design characteristics.

Table 1. The variables of strategy.

\begin{tabular}{|c|c|c|c|}
\hline Strategy & Innovation & Design & Characteristics \\
\hline Variables & $\begin{array}{l}\text { - Technical } \\
\text { innovation } \\
\text { - Commercial } \\
\text { innovation } \\
\text { - Management } \\
\text { innovation }\end{array}$ & $\begin{array}{l}\text { - Reinforcing } \\
\text { R\&D ability } \\
\text { - Reducing } \\
\text { production cost } \\
\text { - Ensuring product } \\
\text { quality } \\
\text { - Uplifting } \\
\text { enterprise image }\end{array}$ & $\begin{array}{l}\text { - Product function } \\
\text { - Product } \\
\text { operation } \\
\text { - Product } \\
\text { appearance } \\
\text { - Product cost }\end{array}$ \\
\hline
\end{tabular}


Table 2. Basic statistics.

\begin{tabular}{cccccc}
\hline & Mean & Sd & IS & DS & DC \\
\hline IS & 3.321 & 0.774 & 1.000 & & \\
DS & 3.627 & 0.685 & 0.598 & 1.000 & \\
DC & 3.859 & 0.773 & 0.612 & 0.781 & 1.000 \\
\hline
\end{tabular}

IS: Innovation strategy; DS: Design strategy; DC: Design characteristics.

Table 3. Accuracy analysis statistics.

\begin{tabular}{ccccccc}
\hline & Item & SL & SE & T-value & CR & AVE \\
\hline IS & IS1 & 0.84 & 0.35 & 10.03 & 0.89 & 0.73 \\
& IS2 & 0.86 & 0.25 & 12.44 & & \\
& IS3 & 0.75 & 0.17 & 19.59 & & \\
DS & DS1 & 0.86 & 0.11 & 35.27 & 0.87 & 0.75 \\
& DS2 & 0.91 & 0.32 & 11.00 & & \\
& DS3 & 0.82 & 0.39 & 10.33 & & \\
& DS4 & 0.91 & 0.28 & 11.46 & & \\
DC & DC1 & 0.84 & 0.19 & 18.89 & 0.91 & 0.79 \\
& DC2 & 0.85 & 0.32 & 11.63 & & \\
& DC3 & 0.89 & 0.22 & 14.86 & & \\
& DC4 & 0.68 & 0.17 & 19.82 & & \\
\hline
\end{tabular}

SL: Standardized loading; SE: Standardized error; CR: Composite reliability; AVE: Average variance extracted.

More importantly, the total AVE was 0.76, higher than the standard value of 0.5 [69].

\subsection{Research Model Fit Assessment}

In this study, Lisrel 8.8 was used in the Structural Equation Modeling (SEM) for the research model fit assessment by the Maximum likelihood method.

SEM is a statistical technique for testing and estimating causal relations using a combination of statistical data and qualitative causal assumptions. SEM allows both confirmatory and exploratory modeling, meaning they are suited to both theory testing and theory development. Confirmatory modeling usually starts out with a hypothesis that gets represented in a causal model. The concepts used in the model must then be operationalized to allow testing of the relationships between the concepts in the model. The model is tested against the obtained measurement data to determine how well the model fits the data. The causal assumptions embedded in the model often have falsifiable implications which can be tested against the data.

The results indicated that: $x^{2} / \mathrm{d} f$ (the ratio of chi square over the degrees of freedom) $=1.375$; goodness-of-fit $(\mathrm{GFI})=0.989$; adjusted goodness of fit index $(\mathrm{AGFI})=$ 0.945 ; comparative fit index $(\mathrm{CFI})=0.974$; incremental fit index $(\mathrm{IFI})=0.981$; and the root mean square error of approximation $($ RMSEA) $=0.047$. Because the evaluation criteria $x^{2} / d f$ was smaller than 2.0 and because GFI, AGFI, CFI, and IFI were bigger than 0.90, RMSEA was smaller than 0.05 [2,69-74]. This indicates a proper total goodness-of-fit.

\subsection{Hypotheses Tests}

The theoretical model investigated in this study contains potential dependent variables and potential independent variables. The influences among potential variables cover direct effects, indirect effect, and total effect.

In Table 4, it is clear that innovation strategy has a direct effect on design strategy and design characteristics. The direct effect value innovation strategy has on design strategy is $0.28(\beta=0.28, t=3.61, p<0.01)$, reaching the significant level. And the direct effect value innovation strategy has on design characteristics is $0.21(\beta=$ $0.22, t=2.87, p<0.05$ ), also reaching the significant level.

Besides, design strategy also has a direct effect on design characteristics, with the direct effect value of $0.65(\beta=$ $0.65, t=7.15, p<0.001$ ), reaching the significant level. Among all direct effects, design strategy has the biggest direct effect on design characteristics, with the direct effect value of 0.65 ; innovation strategy has an direct effect value of 0.28 on design strategy; innovation strategy has a direct effect 0.22 on design characteristics, the lowest direct one.

Table 5 also demonstrates that innovation strategy also has an indirect effect on design characteristics on an effect path of innovation strategy $\rightarrow$ design strategy $\rightarrow$ design characteristics. On the path analysis of indirect effects, the effect vale is $0.18(\beta=0.18, t=3.65, p<$ 0.01 ), reaching the significant level.

Table 4. Direct, indirect, and total effect rules.

\begin{tabular}{cccccc}
\hline & & \multicolumn{2}{c}{ DS } & \multicolumn{2}{c}{ DC } \\
\hline & & $\beta$-value & T-value & $\beta$-value & T-value \\
\hline \multirow{4}{*}{ IS } & Direct effect & 0.28 & $3.61^{* *}$ & 0.22 & $2.87^{*}$ \\
& Indirect effect & -- & -- & 0.18 & $3.65^{*}$ \\
& Total effect & 0.28 & $3.61^{* *}$ & 0.40 & $4.85^{* *}$ \\
& Direct effect & & & 0.65 & $7.15^{* * *}$ \\
\multirow{2}{*}{ DS } & Indirect effect & & & -- & -- \\
& Total effect & & & 0.65 & $7.15^{* * *}$ \\
\hline
\end{tabular}

${ }^{*} p<0.05 ;{ }^{* *} p<0.01 ;{ }^{* * *} p<0.001$.

Table 5. Hypotheses rules.

\begin{tabular}{ccccc}
\hline Hypotheses & Paths & Expected signs & Effect & Results \\
\hline H1 & IS $\rightarrow$ DS & + & 0.27 & Supported \\
H2 & IS $\rightarrow$ DC & + & 0.22 & Supported \\
H3 & DS $\rightarrow$ DC & + & 0.65 & Supported \\
\hline
\end{tabular}


From the above analysis, innovation strategy will directly influence design characteristics, with a direct effect value of 0.22 . In addition, innovation strategy can influence design characteristics through the intervene variable of design strategy (indirect effect value $=0.18$ ). Overall, innovation strategy will have a total effect of 0.40 on design characteristics, indicating the important role innovation strategy plays on design characteristics.

From the analysis of Tables 4 and 5, H1, H2, and H3 are confirmed and supported.

\section{Discussions and Management Implication}

Though design or design strategy can be looked upon as an integral resource in enterprises, a mechanism for product integration, and an important loop in the total innovation chain in enterprises [32-36,75], only cases or conceptual proposals can be seen. Theoretical combination and empirical evidences among variables related to design are rare.

As far as the execution of practical product design is concerned, most studies chose to investigate enterprises or product cases. For the product innovation design issue, it is difficult to clarify the relationships among product innovation, design strategy and the output design characteristics due to some limitations such as the enterprise R\&D capacity and marketing factors for the product innovation case $[39,67]$. Moreover, in the past, the measurement for product innovation strategy and design characteristics was not found. Therefore, the practical executors of product innovation were studied regarding how enterprises conduct product innovation, product design, design characteristics, and the like details in the serial value chain. Such a theoretical and empirical study is hoped to make contribution to the theoretical and practical domains of product innovation design.

The result of confirmatory factor analysis indicated a proper construct validity, the convergent validity and discriminant validity for each variable reaching the statistical requirement. Moreover, results of structural equation modeling also demonstrated a good fitness in the theoretical model and the observed data. The three hypothesis proposed in the study were supported. In other words, the product design characteristics will be influenced by the enterprise innovation strategy and design strategy. Differently put, innovation strategy in an enterprise will have effects on design strategy and product design characteristics. Therefore, the practical product design can coordinate the goal set up in the innovation strategy to fulfill the product innovation through a more efficient integration of R\&D resources and cross-organization coordination in an enterprise. The results obtained in this study can reinforce those in related studies [57-59,76].

More importantly, product design characteristics can make possible the marketization of innovation strategy and serve as concrete criteria for innovation design. This confirmed the study result of [39]. The theoretical model proposed in this study, therefore, can be a reference for survey of enterprise product innovation design in the future.

\section{Limitations and Suggestions}

The major limitation to the present study is that only a single industry (consumer electronic industry) and a single country (Taiwan) is covered. In 2009, Taiwan consumer electronic industry was typically representative in the global market, Top 2 in the world in terms of competition ability. Furthermore, most Taiwanese enterprises have manufacturing plants in Mainland China. Overall, the consumer electronic enterprises in Taiwan and the Taiwan consumer electronic enterprises in Mainland China had the biggest market share in the global market of consumer electronics products. Hence, the obtained results from the study are representative in the global consumer electronic industry.

According to Takeuchi and Nonaka [77], the new product profit would roughly be $30 \%-40 \%$ of the total revenue. Take manufacturing industry in USA for an instance, new products make a contribution of $40 \%$ in the annual revenue and $32 \%$ of profits in a company [78]. Moreover, according to a survey made by Product Development and Management Association (PDMA), 32.4\% of the business turnover of a company came from new product launched in past five years. For hi-tech industry, the percentage is even higher, reaching $42.3 \%$ [21]. The issue of how innovation design makes profit in enterprises will be further investigated in the future.

Moreover, the relationships between design performance and affectivity of strategy can be explored through the perspective of design and innovation performance in different strategic positions and actions. An in-depth exploration of the inter-relation between the strategic execution procedure and organizations is another issue from the approach of design chain. Cases and theoretical models can be further examined to clarify their correlations.

It is a challenge for enterprises to quickly launch a new product that can meet the customers' needs and make profit in the market. This is a first attempt of empirical study on variables regarding the practice of innovation strategy, product design, and design characteristics. Perspective studies regarding innovation variables can be further conducted in the theoretical and practical fields.

\section{Acknowledgements}

The authors would like to thank the National Science Council, Taiwan for financially/partially supporting this research under Contract No. NSC. 


\section{REFERENCES}

[1] G. Hamel and P. Skarzynski, "Innovation: The New Route to Wealth," Journal of Accountancy, Vol. 192, No. 5, 2001, pp. 65-68.

[2] J. Baker, A. Parasuraman, D. Grewal, et al., "The Influence of Multiple Store Environment Cues on Perceived Merchandise Value and Patronage Intentions," Journal of Marketing, Vol. 66, No. 2, 2002, pp. 120-141. doi:10.1509/jmkg.66.2.120.18470

[3] K. Dittrich and G. Duysters, "Networking as a Means to Strategy Change: The Case of Open Innovation in Mobile Telephony," The Journal of Product Innovation Management, Vol. 24, No. 6, 2007, pp. 510-521. doi:10.1111/j.1540-5885.2007.00268.x

[4] K. T. Ulrich and S. D. Eppinger, "Product Design and Development," McGraw-Hill, Irwin, 2004.

[5] A. Booz and Hamilton, "New Products Management for the 1980s," Booz, Allen \& Hamilton, Tysons Corner, 1982.

[6] S. Pugh, "Total Design: Integrated Methods for Successful Product Engineering," Addison-Wesley Publishing, Co., Boston, 1991.

[7] G. Christoph, "Successful Product Development after Firm Acquisitions: The Role of Research and Development," The Journal of Product Innovation Management, Vol. 24, No. 6, 2007, pp. 614-628. doi:10.1111/j.1540-5885.2007.00275.x

[8] R. G. Cooper and E. J. Kleinschmidt, "Success Factors in Product Innovation," Industrial Marketing Management, Vol. 16, No. 3, 1987, pp. 215-233. doi:10.1016/0019-8501(87)90029-0

[9] W. E. Souder and X. M. Song, "Contingent Product Design and Marketing Strategies Influencing New Product Success and Failure in US and Japanese Electronics Firms," The Journal of Product Innovation Management, Vol. 14, No. 1, 1997, pp. 21-34. doi:10.1016/S0737-6782(96)00079-3

[10] K. T. Ulrich and S. Pearson, "Assessing the Importance of Design through Product Archaeology," Management Science, Vol. 44, No. 3, 1998, pp. 352-369. doi: $10.1287 / \mathrm{mnsc} .44 .3 .352$

[11] R. Chhatpar, "Innovate Faster by Melding Design and Strategy," Harvard Business Review, Vol. 85, No. 9, 2007, pp. 30-32.

[12] P. Girard, J. Legardeur and C. Merlo, "Product Innovation through Management of Collaborative Design in Concurrent Engineering," The International Journal of Technology Management \& Sustainable Development, Vol. 6, No. 2, 2007, pp. 151-164. doi:10.1386/ijtm.6.2.151_1

[13] J. McGregor, "The World's Most Innovative Companies," Business Week, 24 April 2006, pp. 63-74.

[14] H. Driva, K. S. Pawar and U. Menon, "Measuring Product Development Performance in Manufacturing Organisations," International Journal of Production Economics, Vol. 63, No. 2, 2000, pp. 147-159. doi:10.1016/S0925-5273(99)00007-9

[15] K. S. Pawar and H. Driva, "Performance Measurement for Product Design and Development in a Manufacturing
Environment," International Journal of Production Economics, Vol. 60-61, No. 1, 1999, pp. 61-68. doi:10.1016/S0925-5273(98)00195-9

[16] B. B. Mozota, "Design Management: Using Design to Build Brand Value and Corporate Innovation," Allworth Press, New York, 2003.

[17] T. Gouws and G. P. V. R. van Oudtshoorn, "Correlation between Brand Longevity and the Diffusion of Innovations Theory," Journal of Public Affairs, Vol. 11, No. 4, 2011, pp. 236-242. doi:10.1002/pa.416

[18] R. W. Veryzer and B. B. D. Mozota, "The Impact of UserOriented Design on New Product Development: An Examination of Fundamental Relationships," The Journal of Product Innovation Management, Vol. 22, No. 2, 2005, pp. 128-143. doi:10.1111/j.0737-6782.2005.00110.x

[19] J. Anderson and C. Markides, "Strategic Innovation at the Base of the Pyramid," MIT Sloan Management Review, Vol. 49, No. 1, 2007, pp. 83-88.

[20] M. Carlsson, "Aspects of the Integration of Technical Functions for Efficient Product Development," $R \& D$ Management, Vol. 21, No. 1, 1991, pp. 55-66. doi:10.1111/j.1467-9310.1991.tb00729.x

[21] A. Griffin and J. R. Hauser, "Integrating R\&D and Marketing: A Review and Analysis of the Literature," The Journal of Product Innovation Management, Vol. 13, No. 3, 1996, pp. 191-215. doi:10.1111/1540-5885.1330191

[22] A. K. Gupta, S. P. Raj and D. L. Wilemon, "R\&D and Marketing Dialogue in High-Tech Firms," Industrial Marketing Management, Vol. 14, No. 4, 1985, pp. 289300. doi:10.1016/0019-8501(85)90022-7

[23] R. W. Ruekert and O. C. Walker Jr., "Interactions between Marketing and R\&D Departments in Implementing Different Business Strategies," Strategic Management Journal, Vol. 8, No. 3, 1987, pp. 233-248. doi:10.1002/smj. 4250080303

[24] M. B. Pinto, J. K. Pinto and J. E. Prescott, “Antecedents and Consequences of Project Team Cross-Functional Cooperation," Management Science, Vol. 39, No. 10, 1993, pp. 1281-1297. doi:10.1287/mnsc.39.10.1281

[25] C. Rusinko, "Design-Manufacturing Integration to Improve New Product Development: The Effects of Some Organization- and Group-Level Practices," Project Management Journal, Vol. 28, No. 2, 1997, pp. 37-46.

[26] X. M. Song, M. M. Montoya-Weiss and J. B. Schmidt, "Antecedents and Consequences of Cross-Functional Cooperation: A Comparison of R\&D, Manufacturing, and Marketing Perspectives," The Journal of Product Innovation Management, Vol. 14, No. 1, 1997, pp. 35-47. doi:10.1111/1540-5885.1410035

[27] E. M. Olson, "Interdependence, Conflict, and Conflict Resolution: Design's Relationships with R\&D, Marketing, and Manufacturing," Design Management Journal, Vol. 5, No. 4, 1994, pp. 60-66.

[28] K. S. Durward II, K. L. Jeffrey and C. W. Allen, "Another Look at How Toyota Integrates Product Development," Harvard Business Review, Vol. 76, No. 4, 1998, pp. 36-47.

[29] R. B. Handfield, G. L. Ragatz, K. J. Petersen, et al., "In- 
volving Suppliers in New Product Development," California Management Review, Vol. 42, No. 1, 1999, pp. 5982. doi: $10.2307 / 41166019$

[30] Andi and T. Minato, "Design Documents Quality in the Japanese Construction Industry: Factors Influencing and Impacts on Construction Process," International Journal of Project Management, Vol. 21, No. 7, 2003, pp. 537546. doi:10.1016/S0263-7863(02)00083-2

[31] Y. Hsu, "Comparative Study of Product Design Strategy and Related Design Issues," Journal of Engineering Design, Vol. 17, No. 4, 2006, pp. 357-370. doi:10.1080/09544820600664655

[32] M. Baxter, "Product Design: A Practical Guide to Systematic Methods of New Product Development," Chapman \& Hall, London, 1995.

[33] W. Olins, "Corporate Identity: Making Business Strategy Visible through Design," Harvard Business School Press, Boston, 1990.

[34] T. Fujimoto, "Product Integrity and the Role of Designer-as-Integrator," Design Management Journal, Vol. 2, No. 2, 1991, pp. 29-34.

[35] M. Bruce and B. H. Jevnaker, "Management of Design Alliances: Sustaining Competitive Advantage," John Wiley \& Sons, England, 1998.

[36] D. Twigg, "Managing Product Development within a Design Chain," International Journal of Operations \& Production Management, Vol. 18, No. 5, 1998, pp. 508-524. doi:10.1108/01443579810206361

[37] C. P. Ge and B. Wang, "An Activity-Based Modelling Approach for Assessing the Key Stakeholder's Corporation in the Eco-Conscious Design of Electronic Products," Journal of Engineering Design, Vol. 18, No. 1, 2007, pp. 55-71. doi:10.1080/09544820600645886

[38] S. Aydin, A. Cetin and G. Ozer, "The Relationship between Marketing and Product Development Process and Their Effects on Firm Performance," Academy of Marketing Studies Journal, Vol. 11, No. 1, 2007, pp. 53-68.

[39] Y. Hsu, "Exploring Design Innovation and Performance: The Roles of Issue Related to Design Strategy," Journal of Engineering Design, Vol. 20, No. 6, 2009, pp. 555-569. doi:10.1080/09544820802043609

[40] R. S. Schuler and S. E. Jackson, "Linking Competitive Strategies with Human Resource Managem," The Academy of Management Executive, Vol. 1, No. 3, 1987, pp. 207-220. doi:10.5465/AME.1987.4275740

[41] J. Tidd and J. Bessant, "Managing Innovation: Integrating Technological, Market and Organizational Change," Wiley, Hoboken, 2009.

[42] J. T. Gilbert, "Choosing an Innovation Strategy: Theory and Practice," Business Horizons, Vol. 37, No. 6, 1994, pp. 16-22. doi:10.1016/S0007-6813(05)80240-X

[43] M. J. Dziura, "Innovation: Sources and Strategies," International Journal of Technology Management, Vol. 21, No. 5-6, 2001, pp. 612-627.

[44] T. D. Kuczmarski, "Managing New Products: The Power of Innovation,” Prentice Hall, Upper Saddle River, 1992.

[45] T. D. Kuczmarski, "Innovation: Leadership Strategies for the Competitive Edge," American Marketing Association, Chicago, 1996.

[46] D. H. Gobeli and D. J. Brown, "Analyzing Product Innovations," Research Management, Vol. 30, No. 4, 1987, pp. 25-31.

[47] A. Johne, "Using Market Vision to Steer Innovation," Technovation, Vol. 19, No. 4, 1999, pp. 203-207. doi:10.1016/S0166-4972(98)00112-6

[48] E. Yoon and G. L. Lilien, "New Industrial Product Performance: The Effects of Market Characteristics and Strategy," The Journal of Product Innovation Management, Vol. 2, No. 3, 1985, pp. 134-144. doi:10.1016/0737-6782(85)90033-5

[49] K. Atuahene-Gima, "Market Orientation and Innovation," Journal of Business Research, Vol. 35, No. 2, 1996, pp. 93-103. doi:10.1016/0148-2963(95)00051-8

[50] G. K. Chacko, "Technology Management: Applications to Corporate Markets and Military Missions," Praeger, Westport, 1988.

[51] A. Subramanian and S. Nilakanta, "Organizational Innovativeness: Exploring the Relationship between Organizational Determinants of Innovation, Types of Innovations, and Measures of Organizational Performance," Omega, Vol. 24, No. 6, 1996, p. 631. doi:10.1016/S0305-0483(96)00031-X

[52] J. M. Higgins, "Innovation: The Core Competence," Planning Review, Vol. 23, No. 6, 1995, pp. 32-36. doi:10.1108/eb054532

[53] S. Silbiger, “The Ten-Day MBA: A Step-by-Step Guide to Mastering the Skills Taught in America's Top Business Schools," Collins, New York, 2005.

[54] C. Marxt and F. Hacklin, "Design, Product Development, Innovation: All the Same in the End? A Short Discussion on Terminology," Journal of Engineering Design, Vol. 16, No. 4, 2005, pp. 413-421. doi: $10.1080 / 09544820500131169$

[55] W. Renee, B. Casper, M. Thomas, et al., "Increasing the Benefits of Product-Level Benchmarking for Strategic Eco-Efficient Decision Making," Benchmarking, Vol. 14, No. 6, 2007, pp. 711-727. doi:10.1108/14635770710834509

[56] T. J. Sung and M. You, “An Empirical Study on Design Strategy and Design Performance of Information Firms in Taiwan," Journal of Design, Vol. 4, No. 1, 1999, pp. 4759.

[57] B. B. D. Mozota, "The Four Powers of Design: A Value Model in Design Management," Design Management Review, Vol. 17, No. 2, 2006, pp. 44-93. doi:10.1111/j.1948-7169.2006.tb00038.x

[58] C. Dell'Era and R. Verganti, "Strategies of Innovation and Imitation of Product Languages," The Journal of Product Innovation Management, Vol. 24, No. 6, 2007, pp. 580-599. doi:10.1111/j.1540-5885.2007.00273.x

[59] S. Sari, T. Leena, S. Mikko, et al., "Executive Views Concerning Decision Support Tools," European Journal of Operational Research, Vol. 181, No. 2, 2007, pp. 929938. doi:10.1016/j.ejor.2006.06.024

[60] W. Chang, "A Study of Design Policy and Design Strat- 
egy in Product Design," Industrial Design, Vol. 27, No. 1, 1998, pp. 2-7.

[61] C. M. Crawford, "New Products Management," 2nd Edition, McGraw-Hill Press, New York, 1994.

[62] E. M. Olson, R. Cooper and S. F. Slater, "Design Strategy and Competitive Advantage," Business Horizons, Vol. 41, No. 2, 1998, pp. 55-61. doi:10.1016/S0007-6813(98)90035-0

[63] M. Oakley, "Design Management: A Handbook of Issues and Methods," Blackwell Reference, Oxford, 1990.

[64] M. E. Porter, "Competitive Strategy: Techniques for Analyzing Industries and Competitors," Free Press, New York, 1980.

[65] L. Kelley, "The Strategy Palette," Communication Art, Vol. 99, 1992.

[66] T. J. Sung and P. Gilmour, “An Empirical Examination of the Relationship between Design, the NPI Process and Strategy Implementation," International Journal of Technology Management, Vol. 24, No. 5-6, 2002, pp. 542-556.

[67] Y. Hsu, "Design Innovation and Marketing Strategy in Successful Product Competition," The Journal of Business \& Industrial Marketing, Vol. 26, No. 4, 2011, pp. 223-236. doi:10.1108/08858621111126974

[68] J. Hulland, "Use of Partial Least Squares (PLS) in Strategic Management Research: A Review of Four Recent Studies," Strategic Management Journal, Vol. 20, No. 2, 1999, pp. 195-204. doi:10.1002/(SICI)1097-0266(199902)20:2<195::AID-S $\underline{\mathrm{MJ} 13>3.0 . \mathrm{CO} ; 2-7}$

[69] D. Gefen, E. Rigdon and D. Straub, "An Update and Extension to SEM Guidelines for Administrative and Social Science Research," MIS Quarterly, Vol. 35, No. 2, 2011, p. 3.

[70] J. F. Hair, "Multivariate Data Analysis," Prentice Hall, Upper Saddle River, 1998.

[71] K. Atuahene-Gima and H. Li, "When Does Trust Matter? Antecedents and Contingent Effects of Supervisee Trust on Performance in Selling New Products in China and the United States," Journal of Marketing, Vol. 66, No. 3, 2002, pp. 61-81. doi:10.1509/jmkg.66.3.61.18501

[72] J. R. Brown, C. S. Dev and D.-J. Lee, "Managing Marketing Channel Opportunism: The Efficacy of Alternative Governance Mechanisms," Journal of Marketing, Vol. 64, No. 2, 2000, pp. 51-65. doi:10.1509/jmkg.64.2.51.17995

[73] J. P. Cannon and C. Homburg, "Buyers-Supplier Relationships and Customer Firm Costs," Journal of Marketing, Vol. 65, No. 1, 2001, pp. 29-41. doi:10.1509/jmkg.65.1.29.18136

[74] C. H. Noble and M. P. Mokwa, "Implementing Marketing Strategies: Developing and Testing a Managerial Theory," Journal of Marketing, Vol. 63, No. 4, 1999, pp. $57-$ 73. doi:10.2307/1251974

[75] S. C. Wheelwright and K. B. Clark, "Revolutionizing Product Development: Quantum Leaps in Speed, Efficiency, and Quality," Free Press, New York, 1992.

[76] D. E. Claudio and V. Roberto, "Strategies of Innovation and Imitation of Product Languages," The Journal of Product Innovation Management, Vol. 24, No. 6, 2007, pp. 580-599. doi:10.1111/j.1540-5885.2007.00273.x

[77] H. Takeuchi and I. Nonaka, "The New Product Development Game," Harvard Business Review, Vol. 64, No. 1, 1986, pp. 137-146.

[78] R. W. Haas, "Industrial Marketing Management: Text and Cases,” PWS-KENT Pub. Co., Boston, 1989. 


\section{Appendix}

1. Variables for innovation strategy

1) Technical innovation

- Invest a higher ratio of $\mathrm{R} \& \mathrm{D}$ expense from the revenue than the counterpart.

- Have a good intelligent royalty management system.

- Being aggressive in the application of patents.

- Have enough key techniques and patents.

- Improve R\&D procedure to reach the company goal.

- Quick launch new products in the market.

- Introduce new techniques to improve manufacturing procedure.

2) Commercial innovation

- Work as a leader in the new product market.

- Fast in adjusting the current product line.

- Offer new products or services that can better meet the customer's demands.

- Commercialize a product faster than the competitors.

- Change or relocate the target customer group for market segmentation.

- New products or techniques are often copied by the competitors.

3) Management innovation

- Take advantage of information technology to accelerate product development and supply chain management.

- Encourage customers to innovate by raising wage or welfare system.

- Stimulate R\&D personnel to innovate by a proper performance measurement system.

- Being flexible and efficient in production and shipment.

- Be able to handle customers' complaints and solve their problems.

- Adopt proper response strategy in time to cope with the change in outer environment.

2. Variables for design strategy

1) Reinforcing R\&D ability

- Work out new products through the acquisition or cooperation with advanced manufacturer.

- Increase the ratio of $R \& D$ and design expense in the revenue to uplift product design and $R \& D$ abilities.

- Reinforce professional NPD know how to improve the efficiency in product design and development.

- Apply new or current techniques and parts to work out products of unique functions.

2) Reducing production cost

- Reduce the total product production cost through subtle selection of parts and materials in the way of working together with other divisions.

- Add functions and values to products under the cost limit through professional design skills.

- Subtly respond to the change in outer environment through the application of product design ability.

- Integrate parts so that it is easy to assembly and main- tain through modulization and standardization in design.

- Uplift the product competition ability through mutual supports in design and production from manufacturers.

3) Ensuring product quality

- Uplift the product reliability, durability, and maintenance to enhance the total product quality standard.

- Ensure products meet the safety regulations and standards.

- Reduce the consumption of energy, materials, and chemicals, minimizing the pollution to the environment.

- Create social and cultural utilities of products through emotional, affective, and life style consideration.

- Apply human factors technique to meet the user's operational needs in hardware or software design of products.

4) Uplifting enterprise image

- Reinforce company and brand images to build up a good reputation in counterparts and customers.

- Enrich competition ability in the market by product differentiation.

- Create and uplift the image or value of enterprise, product, and brand through unique aesthetics, semantic representation, and product form.

- Work out modern and unique products through particular product form feature, colors, and texture.

- Offer better design services and reinforce the promotion in sales by commodity exhibition, advertising, and display.

- Develop new products for different user groups to meet their requirements.

3. Variables for design characteristics

1) Product function

- Offer totally new functions.

- Emphasize the improvement of current functions.

- Offer other additive functions.

- Offer functions similar to the precedent products in current products.

2) Product operation

- Offer totally new way of product operation.

- Adjust the current product operation.

- Offer operations similar to the precedent products in current products.

3) Product appearance

- Emphasize a totally new appearance in products.

- Offer a modification in product appearance.

- Apply serial design technique so that current products look like the precedent products.

4) Product cost

- Adopt a production method of higher cost.

- Emphasize the cost down production method.

- Maintain the cost similar to the precedent products. 